Andrzej Dubicki

Uniwersytet Łódzki

iD ORCID ID: 0000-0002-9949-210X

Tadeusz Dubicki

Uniwersytet Humanistyczno-Przyrodniczy

im. Jana Długosza w Częstochowie
OBLICZA WOJNY

TOM $1 \cdot$ ARMIA KONTRA NATURA ŁóDŹ 2020 • ISBN 978-83-8220-055-3 • s. 141-154 http://dx.doi.org/10.18778/8220-055-3.10

\title{
DUNAJ JAKO PRZESZKODA NATURALNA W OPERACJACH WOJSK RUMUŃSKICH
}

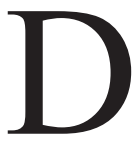

unaj stanowi naturalną barierę odgradzającą Rumunię od jej południowych sąsiadów, niemniej jednak już od czasów starożytnych wiadomo, że nie stanowi on zapory nie do przebycia, udowodnił to Dariusz, król Persów, potem m.in. Aleksander Wielki, Trajan i w średniowieczu wielokrotnie dowódcy otomańscy. Również i w drugą stronę rzeka ta nie stanowiła problemu przy działaniach ofensywnych, dowiodły tego wielokrotnie wojska geto-dackie, czy później gockie dokonujące śmiałych rajdów, czy inwazji na tereny położone na południe od Dunaju. Przekraczano go różnymi sposobami, od użycia najprymitywniejszych środków przeprawowych, po budowę stałych mostów, czego dokonali inżynierowie rzymscy w II i IV w. n.e.

Można stwierdzić, że wraz z rozwojem sztuki wojennej, Dunaj stawał się przeszkodą coraz bardziej ważną i zyskującą na znaczeniu w kontekście istoty sztuki wojennej. Wraz z rozwojem artylerii należało coraz dokładniej planować ewentualną inwazję na tereny położone na południe, należało się także liczyć z możliwym silnym oporem ze strony przeciwnika. Z drugiej strony Dunaj stanowił raczej wyzwanie natury logistycznej niż militarnej, z uwagi na to, iż należało wykorzystać takie miejsca do przeprawy, które umożliwiały przedostanie się na drugi brzeg wraz z taborami i artylerią, konieczną do wspomagania walk na drugim brzegu.

Kampania wojny rosyjsko-rumuńsko-tureckiej z lat 1877-1878 jest przykładem ukazującym rolę Dunaju jako przeszkody naturalnej, umożliwiającej stronie rumuńskiej pewne działania wyznaczające przy okazji modus operandi, który później będzie powtórzony przynajmniej dwukrotnie, w kampanii 1913 i w kampanii $1916 \mathrm{r}$. 
Pierwsze działania planistyczne można zaobserwować jesienią 1876 r., była to: częściowa mobilizacja i koncentracja armii stałej. Wówczas zmobilizowano cztery dywizje: 1 Dywizję w Krajowej i okolicach, 2 Dywizję w Bukareszcie i okolicach, 3 Dywizję w strefie Gałacz-Braiła i 4 Dywizję w okolicach Fokszan ${ }^{1}$. Pierwotne rozmieszczenie odpowiadało przyjętemu pryncypium defensywnemu, dającemu pewną możliwość manewru. Ponadto brak koncentracji wielkich jednostek w pobliżu siebie, a w odległości około $180 \mathrm{~km}$ ( 8 dni marszu) - było rezultatem niepewności, co do rozwoju sytuacji i braku wiedzy, co do tego, gdzie nastąpi starcie z przeciwnikiem. Obawy, które finalnie miały okazać się płonne, były do pewnego stopnia uzasadnione, gdyż według świadectwa Williama V. Herberta, Osman Pasza planował uderzenie na Rumunię od południowego zachodu, które miała rozpocząć się od przekroczenia Dunaju w okolicach Widyń-Calafat. Operacja miała być zatrzymana na rozkaz ze stolicy Imperium Osmańskiego².

Konkretne działania przygotowujące przekroczenie Dunaju rozpoczęto w kwietniu 1877 r., po tym, jak zdano sobie sprawę z tego, że wojna z Turcją jest raczej nieunikniona. Wcześniej wprawdzie Rumunia zgodziła się na przejście wojsk rosyjskich przez własne terytorium, natomiast poza tym działaniem Rosjanie raczej sami byli przeciwni czynnemu udziałowi Rumunów w kampanii, sugerując, by Rumuni ograniczyli się do obrony własnych (przy okazji i rosyjskich) tyłów przeciw możliwym napadom strony tureckiej. Ostatecznie 6 kwietnia 1877 r. rząd rumuński zdecydował o przeprowadzeniu mobilizacji. Rumuni mogli wówczas zmobilizować 130 tys. żołnierzy, co stanowiło dziewięciokrotność stanu armii na stopie pokojowej (17 800 żołnierzy) ${ }^{3}$. Opracowany wtedy plan działań, który możemy odtworzyć pośrednio z podjętych działań defensywnych - przewidywał początkowo przeciwdziałanie $\mathrm{z}$ uwagi na możliwość: ataku tureckiego w sektorze Calafat (czyli z kierunku twierdzy Widyń) i dalszy marsz Turków w kierunku Krajowej w celu przerwania linii kolejowej Turnu-Severin (granica z Austro-Węgrami)-Bukareszt, bądź - tradycyjnej, ostatnio użytej w 1848 r. możliwości działań, czyli forsowania Dunaju w Giurgiu lub Olteniţy z kierunkiem uderzenia na Bukareszt. Z kolei strona turecka zakładała - zniszczenie mostu kolejowego w Barboşi (okolice Braiły, obszar gdzie kolej najbardziej zbliżała się do Dunaju), co miałoby spore znaczenie militarne, z uwagi na przecięcie jedynej linii kolejowej w Rumunii i generowałoby kolejne problemy z zaopatrzeniem armii rosyjskiej walczącej na Bałkanach ${ }^{4}$. Jak się miało okazać, tureckie plany wojenne właściwie

${ }^{1}$ R. Rosetti, Proiecte de operaţiuni in anii 1876-1878, „Analele Academiei Române” Memoriile secţiunii istorice, seria III, t. XXVII, em. 4, București 1945, s. 65.

${ }^{2}$ Ibidem, s. 6.

${ }^{3}$ G. Petre, G. Boranda, Noi contribuţii la studierea răzaboiului pe Dunăre. 1877-1878. Studii Documentare, București 2007, s. 11.

${ }^{4}$ Ibidem, s. 11. 
nie zakładały prawdziwego desantu na północnym brzegu rzeki. Było to niewykorzystanie potencjału bojowego i oznaczało praktyczne „odpuszczenie” sobie pierwszej linii obrony, jaką stanowił Dunaj. Flota turecka nie była zbyt aktywna, co z kolei znakomicie ułatwiało działania Rosjanom, czy później Rumunom. Turcy mieli o tyle silną pozycję, że utrzymywali w swych rękach ujście Dunaju, co oznaczało, że wszystkie środki przeprawowe musiały właściwie pochodzić z terenu Rumunii, względnie Besarabii 5 .

Później, w maju 1877 r., w czasie rozmów z Rosjanami - rozpatrywano już wariant działań ofensywnych wojsk rumuńskich, mianowicie uderzenie w kierunku Widynia, później jeszcze dołożono do tego możliwość przerwania komunikacji pomiędzy Plewną a Sofią. Działania ofensywne strony rumuńskiej wynikały z chęci większego zaznaczenia własnej obecności w wojnie. W założeniach rumuńskich, granicą operacyjną między sektorem rosyjskim a rumuńskim na południowym brzegu Dunaju miała być rzeka Iskyr ${ }^{6}$. Plany akcji w kierunku Widynia zostały jednak zarzucone w połowie $1877 \mathrm{r}$. z uwagi na problemy pod Plewną, Rumuni nie porzucili jednak pomysłu przekroczenia Wielkiej Rzeki, jednak zmienili kierunek potencjalnej akcji, w kierunku wschodnim, tak aby atak ułatwił dalsze działania pod Plewną.

Przejście Dunaju przez Rumunów było także istotne z uwagi na potrzebę osłony prawego skrzydła armii rosyjskiej operującej w północnej Bułgarii i oblegającej Plewnę. Miało mieć też wydźwięk humanitarny i przynieść wyzwolenie ludności bułgarskiej spod okupacji tureckiej - dać jej wytchnienie w czasie wojny. Pierwotny plan zakładał przekroczenie Dunaju na odcinku Salcea-Negotin. Miejsce to wybrano z kilku względów: brzeg rumuński dominował nad brzegiem tureckim, co dawało wgląd w pozycje przeciwnika, dawało także większy zasięg artylerii, jak również uniemożliwiało przedostanie się na miejsce desantu tureckim jednostkom rzecznym. Prace przygotowawcze rozpoczęto 9/21 lipca, niemniej jednak ostatecznie od tego planu odstąpiono z uwagi na utratę czynnika zaskoczenia ${ }^{7}$. Rozpoczęły się studia nad poszukiwaniem innego miejsca do przekroczenia rzeki, musiały one zostać przyspieszone z uwagi na pogarszającą się sytuację Rosjan pod Plewną. Pojawiło się w międzyczasie sugerowane przez gen. Dodę miejsce przekroczenia pod Bechet, lecz koncepcja ta szybko upadła, gdyż warunki naturalne nie sprzyjały tam Rumunom, ponadto Rahova była obsadzona przez siły tureckie i punkt przejścia leżał zbyt daleko od drogi na Plewnę. Dlatego ostatecznie zdecydowano się na przejście w punkcie Silliştioara-Măgura ${ }^{8}$. W trakcie działań wojennych ostatecznie przeprowadzono: obronę

\footnotetext{
${ }^{5}$ E. Botez, N. Kiriţescu, Războiul pe Dunăre, Bucureşti 2007, s. 78.

${ }^{6}$ Istoria militară a poprului Român, vol. IV, București 1987, s. 610.

${ }^{7}$ R. RosetTi, op. cit., s. 72.

${ }^{8}$ Ibidem, s. 75.
} 
Dunaju do czasu dotarcia wojsk rosyjskich, później przeniesienie ciężaru operacji na ewentualne walki obronne w strefie Turnu Severin - Corabia.

Ostrzał brzegu rumuńskiego Turcy rozpoczęli już w kwietniu 1877 r. - podjęły takie działania przede wszystkim monitory tureckie bombardujące Olteniţę, Bechet i Călăraşi, oraz uniemożliwiające żeglugę na Dunaju. Dnia 26 kwietnia artyleria twierdzy w Widyniu rozpoczęła bombardowanie umocnień rumuńskich w Calafat, zaś artyleria rumuńska nie pozostawała dłużna. Działania skupiały się na wzajemnej wymianie ognia pomiędzy punktami umocnionymi po obu stronach rzeki (dodatkowo jeszcze Olteniţa-Turtucaia). W samym Calafat przeciw Widyniowi skoncentrowano 8 baterii artyleryjskich posiadających działa 88 i $150 \mathrm{~mm}$ z zadaniem ostrzału twierdzy tureckiej, względnie ostrzału Dunaju.

Kampania 1877 r. rozpoczęła się dla Rumunów od działań o charakterze nieregularnym - obie strony wysyłały na drugą stronę rzeki małe oddziałki, które wypełniały zadania o charakterze rozpoznawczym, a także (zwłaszcza w przypadku tureckim) terroryzowały miejscową ludność swoimi napadami o charakterze rabunkowym ${ }^{9}$. Po stronie rumuńskiej w działaniach obronnych zaangażowane były głównie jednostki obrony terytorialnej, rozmieszczone w tym celu nad rzeką, które dość skutecznie starały się przeszkadzać Turkom. Siły regularne znajdowały się przede wszystkim w regionie bramy fokszańskiej, gdzie ich głównym zadaniem była osłona linii kolejowej, jak już wspomniano - potencjalnie podatnej na przerwanie w okolicach Barboşi. W tym celu skoncentrowano tam rumuńską 3 i 4 Dywizję Piechoty oraz wybudowano nad Dunajem stanowiska artylerii, mającej za zadanie odpędzić od dogodnych pozycji strzeleckich tureckie monitory mogące swym ogniem zniszczyć linię kolejową, bądź most na Serecie - wówczas jedyne dogodne połączenie między Mołdawią a południową Besarabią.

Rumuni swe działania rozpoznawcze zintensyfikowali w lipcu 1877 r., starając się rozpoznać miejsce własnego przekroczenia Dunaju. Podobnie jak przy odpieraniu napadów tureckich, $\mathrm{w}$ działania tych były zaangażowane przede wszystkim oddziały terytorialne, znające dobrze teren, przynajmniej po własnej stronie rzeki i przez to mogące skuteczniej działać w kierunku właściwego rozpoznania przyszłego pola walki. Zasłużyły się tu głównie pododdziały 10, 15 i 16 pułku dorobanţi. Jednocześnie Turcy rozpoczęli ostrzał brzegu rumuńskiego z twierdzy Widyń (Calafat), na co Rumuni odpowiedzieli ostrzałem z własnego terytorium. Jako pierwsi rzekę przekroczyli Rosjanie w dwóch miejscach: 9/10 czerwca w strefie Măcin, w tym wypadku desant miał miejsce za pomocą doraźnie zorganizowanych środków przeprawowych, zaś główne siły rosyjskie przebyły rzekę 14/15 czerwca pomiędzy Zimnicea a Swisztowem. W ramach przygotowań do przeprawy Stawka poprosiła stronę rumuńską o bombardowanie brzegu

9 V.I. Mocanu, Botezul de foc al tinerei armate române (pagini de eroism din Războiul pentru Independenţa: 1877-1878), București 2007, s. 26. 
tureckiego na jak największej długości rzeki, aby Turcy do końca nie wiedzieli, gdzie nastąpi przekroczenie rzeki. Szczególna koncentracja ognia rumuńskiego miała miejsce w okolicach Măgura, Rahovej i Widynia. Były to punkty koncentracji sił tureckich, które należało osłabić w oczekiwaniu na właściwy desant.

Turcy ze swej strony również próbowali przekroczyć poważnymi siłami Dunaj, zwłaszcza już po pojawieniu się na południowej stronie rzeki sił rosyjskich, spodziewając się, że zmusiłoby to wojska rumuńsko-rosyjskie do przynajmniej częściowego wstrzymania ofensywy. Problemem dla Turków było ewentualne zdobycie twierdzy w Calafat, która przedstawiała spory potencjał obronny. W 1854 r. udało się im utrzymać tam kilka miesięcy w walkach z Rosjanami, którzy na dodatek nie atakowali twierdzy od strony rzeki. Turcy z kolei mogliby próbować przejść rzekę w sektorach Gârla Mare - Cetate lub Ciuperceni-Desa, lecz dowództwo rumuńskie uznało, że takie działanie Turków jest raczej niemożliwe.

Jednostki rumuńskie przekroczyły Dunaj 20 sierpnia/1 września 1877 r. po moście pontonowym budowanym od 14/26 sierpnia w odległości $2 \mathrm{~km}$ od Corabii na odcinku Siliştioara-Măgura (Zagrażdien). Długość mostu wynosiła $1240 \mathrm{~m}$, a do jego zmontowania użyto 120 pontonów, dzięki którym most rozciągał się na $800 \mathrm{~m}$ lustra wody (pozostałe $440 \mathrm{~m}$ to inne przeszkody terenowe, wysepki rzeczne itp.), łączna długość obiektów inżynierskich zbudowanej przy tej okazji to $3 \mathrm{~km}$. Dodatkowo do obrony mostu wyznaczono okręty flotylli rzecznej i 2 baterie artylerii (12 dział) rozlokowane na wyspie na środku rzeki. Most był ponadto chroniony przez sieci przeciwtorpedowe. Turcy nie próbowali przeciwdziałać w trakcie budowy mostu. Przyczółek był zabezpieczany przez jednostki, które już wcześniej Rumuni przerzucili na drugą stronę rzeki, zresztą nie bez kłopotów związanych z doraźnym brakiem środków przeprawowych. Ostatecznie jednak wszystko się udało, przyczółek został zabezpieczony tak, aby przejście Dunaju mogło się odbyć z pełną pompą. Pojawił się wtedy na miejscu książę Karol, rząd rumuński, przedstawiciele parlamentu i dużo publiczności. Przejście odbyło się bezproblemowo. Sam most został później spławiony w kierunku Nikopola, gdzie zapewniał komunikację z siłami rumuńskimi oblegającymi Plewnę. Most utrzymano do początku grudnia 1877 r., po czym został rozmontowany $z$ uwagi na nadciągającą zimę. Budowa mostu własnymi siłami i jego wykorzystanie głównie przez siły rumuńskie było traktowane również propagandowo, jako dowód na zaawansowanie i rozwój jednostek inżynieryjnych wojska rumuńskiego.

Druga $\mathrm{z}$ ofensywnych kampanii rumuńskich skierowana była przeciw Bułgarii. Również i w tym przypadku konieczne było przede wszystkim sforsowanie Dunaju w celu zajęcia Sofii i finalnego wyłączenia Bułgarii z II wojny bałkańskiej. Wiele już napisano o przyczynach wojny międzysojuszniczej, jak często określa 
się właśnie to starcie ${ }^{10}$. Rumunia była w tym czasie niezadowolona ze wzrastającej roli Bułgarii w regionie Bałkanów, zwłaszcza iż wyraźnie odczuwano zwiększone zainteresowanie Niemiec i Austro-Wegier tym krajem, będącym bramą do Turcji, w której Niemcy również mieli ambicję zdobyć swoje wpływy. Elementem mającym - według władz rumuńskich - ustabilizować sytuację, miało być przekazanie Rumunii twierdz naddunajskich. Najpierw Sillistrii - później, po udanej dla Bułgarii kampanii 1912-1913 doszło do tego żądanie przekazania Turtakanu (Turtucaia). Dobrudżę południową upatrywano wówczas jako potencjalne miejsce do kolonizacji przez ludność rumuńską, podobnie jak miało to miejsce w przypadku pozostałej części Dobrudży po wojnie $1877-1878^{11}$. Dodatkowym aspektem działań była chęć wykazania pewnej niezależności w stosunku do Austro-Węgier, które dość mocno naciskały na Rumunów, by ci powstrzymali się od agresywnych kroków przeciw Bułgarii. Najważniejszą konkluzją w kontekście rumuńskim jest ta negująca właściwie taki charakter wojny. Zresztą według własnej propagandy: armia rumuńska interweniowała w Bułgarii w celu „przywrócenia pokoju”. Warto nadmienić, że Rumunia, atakując Bułgarię, de facto nie miała żadnego porozumienia z pozostałymi uczestnikami Ligi Bałkańskiej i Turcją. Niemniej jednak warto nadmienić, że zarówno Serbia, jak i Grecja, dążyły do zawarcia jakiejś formy układu politycznego. Ostatecznie do tego nie doszło, częściowo także zapewne z braku czasu. Sprawę załatwiono doraźnie, delegując do sztabów armii serbskiej i greckiej oficerów z osobistego polecenia króla Karola I. Delegatem w Belgradzie został ówczesny ppłk Henri Cihoski $(20$ czerwca/2 lipca 1913), jako attaché wojskowy, i płk Constantin Christescu, zastępca szefa Sztabu Głównego (22 czerwca/5 lipca 1913). Do Aten wysłano jako oficera łącznikowego mjr. Ioana Răşcanu, szefa Biura Operacyjnego Sztabu Głównego. Najważniejsze zadanie spoczywało na płk. C. Christescu, który koordynował plany działania, zarówno rumuńskie, jak i serbskie. Serbowie dla podniesienia morale własnych wojsk ogłosili przybycie rumuńskiej delegacji, niemniej jednak nie można mówić o daleko idącej współpracy rumuńsko-serbskiej. Wiadomo, że Serbowie poprosili Rumunów o pomoc przy oblężeniu Widynia, leżącego po drugiej stronie Dunaju, więc łatwego do zbombardowania przez siły rumuńskie nawet $\mathrm{z}$ własnego brzegu, co zresztą Rumuni z powodzeniem czynili w trakcie wojny $1877 \mathrm{r}$. Tym razem jednak Rumuni odmówili pomocy i Serbowie bezskutecznie oblegali twierdzę aż do końca wojny ${ }^{12}$.

10 Patrz np. A. Krzak, Wojny bałkańskie 1912-1913, Częstochowa 2017, s. 6.

11 W danym momencie ludność rumuńska stanowiła w południowej Dobrudży około 5\% mieszkańców, resztę stanowili Bułgarzy i Turcy. D. CAIN, Cadrilaterul în relaţiile româno-bulgare (1913-1916), „Astra Sabesiensis” 2017, nr 3, s. 12.

12 P. OŢu, Consideraţii privind capacitatea operativă şi acţiunile armatei române în anul 1913, [w:] Al doilea Război balcanic (1913), ed. M.E. Ionescu, N.Ş. TĂNĂşocA, Bucureşti 2014, s. 132 [126-160]. 
Można zadać pytanie o źródła takiego zachowania wobec Serbów. Odpowiedź nie będzie w tym wypadku prosta. Oczywiście można tu wskazać na brak porozumienia polityczno-wojskowego z Belgradem, jednak zapewne nie była to okoliczność decydująca. Bardziej prawdopodobną przyczyną swoistej bierności Rumunii w tej sprawie był stan rumuńskich sił zbrojnych, oceniany zresztą bardzo krytycznie przez samo dowództwo armii. Dysponujemy tu napisanym post factum raportem gen. Alexandru Averescu, który samokrytycznie negatywnie ocenił udział armii rumuńskiej w wojnie. Armia rumuńska była przygotowana jedynie na krótką kampanię i nie mogła uwikłać się w potencjalne długotrwałe oblężenia, skutkujące, co zrozumiałe, dużym zużyciem amunicji. Największe jednak braki zanotowano w kontekście służb sanitarnych, które nie mogły sobie poradzić z bieżącymi potrzebami wynikającymi po prostu z tego, co działo się na polu bitwy, nie wspominając już o walce z epidemią cholery. Za zaistnienie takiego stanu rzeczy winiono powszechnie polityków - głosy te pochodziły od czynnych uczestników kampanii, zresztą też polityków, czy to aktywnych, czy też podejmujących działalność polityczną w późniejszym czasie (N. Iorga, C. Argetoianu $)^{13}$. Decydenci rumuńscy zdawali sobie sprawę z braków i w okresie bezpośrednio poprzedzającym wojnę $\mathrm{w}$ trybie pilnym starano się dokapitalizować armię i dokonać zakupów interwencyjnych, niemniej jednak nie były one w stanie wypełnić wszystkich braków.

Armia rumuńska rozpoczęła mobilizację 20 czerwca 1913 r., wraz z atakiem Bułgarów na Serbię i Grecję, dodatkowo wolną rękę w tej mierze uzyskano od Niemiec. W nocy z 22 na 23 czerwca rozpoczęto działania wojenne przeciw Bułgarii. Powołano pod broń roczniki 1901-1911, zaś starsze tylko w miarę potrzeby. Mobilizacja została zakończona w 8 dni, co zaskoczyło w pewnym stopniu Bułgarów, którzy spodziewali się jej zakończenia po 14 dniach. Jakość dowodzenia wojskiem rumuńskim także pozostawiała wiele do życzenia, naczelnym wodzem został mianowany następca tronu ks. Ferdynand, który raczej ograniczał się do tzw. nadzoru ogólnego, niemniej jednak z reguły nie pozostawał w dobrych relacjach z gen. A. Averescu, szefem Sztabu Głównego. Sporo do powiedzenia miał także gen. Constantin Hârjeu, minister wojny w ówczesnym rządzie Take Ionescu. Do chaosu w kwestii dowodzenia dokładał się także całkowity brak rozpoznania terytorium wroga, a wręcz poleganie na oficjalnie zdobytych informacjach, które bardziej ocierały się o propagandę niż o rzeczywistość. Przykładem może być rumuńskie przekonanie o jakości dróg w Bułgarii - wszyscy wiedzieli, że raczej nie są one pierwszej klasy. Sztab rumuński tymczasem za dobrą monetę przyjął dane pozyskane na wystawie światowej w Liège, gdzie Bułgarzy twierdzili, że ich kraj dysponuje dobrą siecią dróg. Oczywiście rzeczywistość była zupełnie inna ${ }^{14}$.

\footnotetext{
13 Ibidem, s. 135.

14 P. OŢU, op. cit., s. 146.
} 
Kampania przeciwko Bułgarii oparta była na opracowanym przez sztab rumuński - przy znacznym wkładzie gen. A. Averescu - planie znanym pod nazwą kodową: Ipoteza $n r 1$ bis ${ }^{15}$. Za podstawę owych założeń posłużył opracowany przez wspomnianego generała dokument: Memoriul privitor la îndrumarea operaţiunilor armatei române în cazul că ar interveni în conflictul sârbo-bulgar ${ }^{16}$. Plan wojny zakładał możliwość ataku na dwóch kierunkach: pierwszym - uderzenie w stronę centrum politycznego Bułgarii - czyli Sofii, oraz drugim - możliwość natarcia na kierunku Ruszczuk-Warna, czyli w stronę tzw. Cadrilater (Czworokąta), z zadaniem podkreślenia roszczeń terytorialnych Rumunii. Takie rozmieszczenie armii dawało w pierwszej możliwości - pole do rozpoczęcia akcji czysto wojskowej, natomiast w drugiej opcji - akcji o charakterze politycznym, obliczonej przede wszystkim na przejęcie południowej Dobrudży, do której wcześniej Rumuni zgłaszali pretensje. Należy dodać, że dla nich właściwie każdy kierunek był obiecujący, gdyż wojska bułgarskie nie stacjonowały w swej masie na Dunaju, nie licząc się z możliwością ataku rumuńskiego, względnie licząc na to, iż Rumuni będą mobilizować swe siły przez dłuższy czas. Ponieważ centrum strategicznym Bułgarów było Kustendil, dostęp tam był możliwy jedynie poprzez Sofię, więc głównym celem rumuńskiego ataku musiała być stolica Bułgarii. Zajęcie tego obszaru, poza oczywistym znaczeniem moralnym, oznaczałoby rozdzielenie sił bułgarskich na dwie części, co mogłoby hipotetycznie oznaczać zakończenie wojny. W każdym wypadku w wyniku ataku na odcinku sofijskim Bułgaria byłaby zagrożona zarówno przez siły serbskie, jak i rumuńskie. Wszystkie strategiczne rozwiązania problemu prowadziły do kluczowego elementu, jakim był czas. Rumuni nie mogli dopuścić do pokonania przez Bułgarię armii serbskiej, gdyż to zagroziłoby później marszowi armii rumuńskiej. Kluczowym wyborem w tym wypadku był dobór bazy operacyjnej, co z kolei wiązało się z koniecznością wyboru odpowiedniego miejsca przekroczenia Dunaju. Według A. Averescu, najlepszy fragment do przeprowadzenia desantu znajdował się pomiędzy Bechet a Turnu Magurele. Był to obszar stosunkowo dobrze skomunikowany z resztą kraju, przynajmniej dwiema liniami kolejowymi Costeşti-Turnu Magurele oraz Piatra-Corabia, co zwiększało możliwości koncentracji armii. Również z drugiej strony rzeki istniała linia kolejowa do Sofii, co zwiększało możliwości operacyjne. Jako najbezpieczniejsze uznano potencjalne przejście przez rzekę w sektorze Bechet-Turnu-Măgurele, gdzie nie spodziewano się właściwie żadnego oporu ze strony bułgarskiej. Najwłaściwszym rozwiązaniem byłaby koordynacja działań z Serbami, której jednak, jak wiadomo, ostatecznie nie osiągnięto, niemniej gros sił bułgarskich w sektorze i tak było zajęte obroną Widynia przed Serbami, co dawało Rumunom wolną rękę. Sektor Bechet-Turnu Măgurele miał być o tyle najlepszy dla działań, że miały się

15 Istoria Militara a poporului Român, vol. V, Bucureşti 1988, s. 275.

16 AICB, Casa Regala, 2/1913, f. 2-12. 
tam znajdować jakoby dobre drogi (co, jak już wspomniano, nie było prawdą). Przejście w Corabii miało być mniej dogodne, gdyż znajdowała się tam jedynie droga klasy gminnej (czyli polna). Plan rumuński zakładał przekroczenie rzeki po 10 dniach mobilizacji przez siły osłonowe, mające uchwycić przyczółek w Corabii, gdzie również po 10 dniach miała się rozpocząć budowa mostu pontonowego. Miał on być wykorzystany dwunastego i trzynastego dnia od ogłoszenia mobilizacji.

Armia rumuńska została przerzucona na drugą stronę Dunaju dość sprawnie. Na brzeg bułgarski w okolicach Bechet-Rahova został przeprawiony I Korpus Armijny za pomocą statków, barek i innych jednostek pływających. W tym wypadku przejście całości sił zajęło 4 dni, choć główne siły przewidziane do operacji przedostały się przez Dunaj w ciągu jednego dnia (przeprawa była osłaniana przez rzeczne siły rumuńskie). W kampanii wykorzystano też jeszcze dwa inne przejścia, jedno przez most pontonowy w okolicy Turnu Măgurele - Corabia (mniej więcej w tym samym miejscu, co w poprzedniej wojnie $\mathrm{z}$ Turcją). Tu budowa mostu rozpoczęła się o godz. 8.00 i trwała 7,5 godz., dzięki czemu wieczorem dwie brygady piechoty znalazły się już na drugim brzegu rzeki. Kolejne przejście było możliwe przez stały most drogowo-kolejowy Cernavoda-Feteşti. Istnienie stałej przeprawy kolejowo-drogowej warunkowało potrzebę obrony tej budowli inżynieryjnej - odpowiadała za te działania marynarka rumuńska ${ }^{17}$. Z punktu widzenia strategicznego i taktycznego, armia rumuńska odniosła pełen sukces, udanie przekraczając rzekę i potem stosunkowo szybko zagrażając Sofii, co zmusiło Bułgarów - wraz z innymi niepowodzeniami - do prośby o pokój ${ }^{18}$.

Po zakończeniu działań wojennych i po podpisaniu pokoju, armia rumuńska musiała powrócić przez Dunaj. W tzw. międzyczasie, most został przeniesiony z Corabii do Swisztowa $\mathrm{z}$ uwagi na wysoki stan wód w pierwotnej lokalizacji, co z kolei było rezultatem powodzi, jakie nawiedziły wówczas Rumunię. Był to jedynie pierwszy z problemów, jakie dotknęły stronę rumuńską. O ile marsz w kierunku Sofii był przeprowadzony w miarę skutecznie i w dobrym porządku, o tyle droga powrotna była katastrofą, w której właściwie zawiodła koordynacja. Dodatkowo, chaos spotęgowała decyzja dyrekcji CFR o braku priorytetu dla transportów wojskowych na liniach prowadzących w kierunku Dunaju, co z kolei ograniczyło wykorzystane w czasie mobilizacji zdolności przewozowe o połowę. To zaś wymusiło koncentrację żołnierzy przez dłuższy czas w przejściowych obozowiskach, a jeśli dodamy do tego zawleczoną z Bułgarii epidemię cholery - tragizm sytuacji stanie się jasny. Trzeba tu dodać, iż mosty były rozbierane od 19 sierpnia, gdy o godz. 17.00 rozpoczęto demontowanie przeprawy na wysokości Turnu

${ }^{17}$ M. Moșneagu, Misiunile Marinei Române în al doilea război balcanic, [w:] Al Doilea Război..., s. 164 [161-180].

${ }^{18}$ Gh. BOARU, Contextul politico-militar al intrării României în primul război mondial, „Revista Academiei de Științe ale Securităţii Naţionale" 2018, nr 2, s. 40 [31-50]. 
Măgurele. Napotkano jednak na wiele trudności, przez co ostatecznie prace te trwały 4 dni. Druga przeprawa w Zimnicea została rozmontowana 20 sierpnia a następnego dnia spławiona w dół rzeki.

Co ciekawe, właściwie żadna ze stron konfliktu nie zakładała obrony na Dunaju. Było to z jednej strony logiczne, gdyż na pierwszy rzut oka widać było, że nie da się bronić całej długości rzeki, natomiast $\mathrm{z}$ drugiej strony można było spodziewać się ataku rumuńskiego jedynie w określonych miejscach. Można więc założyć, że atak rumuński właściwie całkowicie zaskoczył Bułgarów, choć mogli się oni spodziewać akcji rumuńskiej, zwłaszcza po uprzednim przedstawieniu ultimatum przez władze rumuńskie. Można się również poważnie zastanawiać nad znaczeniem tego obszaru dla Rumunii i jej dalszej polityki, zwłaszcza w kontekście nadchodzącego konfliktu światowego. Nawet obecnie część naukowców rumuńskich uważa, że była to przysłowiowa bomba z opóźnionym zapłonem, bowiem zdawano sobie sprawę $\mathrm{z}$ tego, że stosunek Bułgarów do Rumunów po II wojnie bałkańskiej uległ diametralnej przemianie. Rumuńscy politycy również mieli tego świadomość i w trakcie negocjacji poprzedzających wejście Rumunii do I wojny światowej starali się traktować południową Dobrudżę jako kartę przetargową, mającą skłonić Bułgarię przynajmniej do neutralności w konflikcie (Rumuni byli w stanie zrezygnować z nowo przyłączonej prowincji).

W przededniu I wojny światowej, w ówczesnych warunkach geopolitycznych, czyli sekretnego uczestnictwa w Trójprzymierzu - strona rumuńska przygotowywała swój plan wojny nazywany Ipoteza $C$, zakładający wystąpienie przeciwko Rosji, co ciekawe przy założeniu wrogości Bułgarii. Po ogłoszeniu neutralności w 1914 r., rozpoczęto także opracowywanie założeń wojny przeciwko państwom centralnym - przede wszystkim była to Ipoteza $B$, zakładająca wrogie nastawienie Bułgarii do Rumunii (rewanż za rok 1913). W związku z tym, postulowano prowadzenie ofensywy przeciw Austro-Węgrom, przy prowadzeniu jedynie działań defensywnych przeciwko Bułgarii (1915). Przygotowywano także działanie na wypadek wytworzenia się bardziej optymistycznych okoliczności, mianowicie zachowania przez Bułgarię neutralności w przypadku wojny Rumunii z państwami centralnymi - była to Ipoteza B1. W takim wypadku wojska rumuńskie miały atakować całością sił w kierunku Siedmiogrodu, nie pozostawiając właściwie żadnego zabezpieczenia na granicy bułgarskiej. Ostatecznie, po zawarciu konwencji wojskowej z Ententą, opracowano założenia kolejnego planu, w zasadzie powielającego założenia Ipotezy B, czyli konfliktu na pełną skalę z wszystkimi krajami wchodzącymi w skład sojuszu państw centralnych. Za głównego przeciwnika uznano Austro-Węgry, przeciw którym zdecydowano się na przeprowadzenie ofensywy, planując na kierunku południowym jedynie działania o charakterze obronnym, zresztą niezbyt spodziewano się otwartego ataku bułgarskiego. Miało się to okazać poważnym błędem. Ostatecznie plan wojny przyjęty przez naczelne 
dowództwo rumuńskie został określony jako Ipoteza B3, lepiej znana też później jako Ipoteza Z. Co istotne, Rumuni kilkukrotnie odrzucali propozycje przyszłych sojuszników: Francuzów i Rosjan, którzy, jak się w przyszłości miało okazać, rozsądniej doradzali przyjęcie opcji szybkiego i silnego ataku na Bułgarię, celem wyłączenia jej z wojny przy prowadzeniu defensywnej walki w Ardealu, zanim państwa centralne zorganizowałyby kontrofensywę, którą zresztą łatwiej byłoby powstrzymać, nawet na dość rozciągniętym górskim froncie w Karpatach. Wymagałoby to prowadzenia aktywnej obrony 19 przełęczy górskich. Walka przeciw Bułgarii byłaby o tyle ułatwiona, że armia bułgarska nie mogła skierować większości swych sił do działań na froncie północnym, będąc zagrożoną od południa na froncie salonickim przez siły greckie. Dodatkowo potencjalny sukces wojny z Bułgarią zmieniłby sytuację wojenną na Bałkanach, gdyż pogorszyłby sytuację Turcji, izolując ją od reszty państw centralnych. Rumuni jednak postawili na opcję „propagandową", zgodną z oficjalną ideologią przystąpienia do wojny i traktowania jej jako narodowowyzwoleńczej w stosunku do Rumunów mieszkujących w Siedmiogrodzie.

Jednym z najsłynniejszych manewrów strategicznych A. Averescu, który jednak ostatecznie okazał się jedynie doraźnym sukcesem taktycznym, były walki nad Dunajem i jedyna rumuńska akcja zaczepna na tym terenie (Operacja „Flamânda”). Jej planowanie rozpoczęto w połowie września 1916 r., w obliczu niesprzyjającej sytuacji militarnej w Dobrudży, gdzie jednostki rumuńskie niespodziewanie dla własnego dowództwa wycofywały się na północ, opuszczając tereny zajęte po II wojnie bałkańskiej - tracąc po krótkiej walce twierdzę Turtucaia (Turtakan). W odniesieniu do jej znaczenia, widać było dużą różnicę zdań $\mathrm{w}$ dowództwie rumuńskim. $Z$ jednej strony twierdza ta uznawana była za trudną do zdobycia, toteż miała $\mathrm{w}$ planach rumuńskich stanowić długotrwały punkt oporu w Dobrudży. Szybki jej upadek stanowił szok dla Rumunów, którzy nie spodziewali się takiego obrotu sprawy. Niemniej kwestia tej twierdzy boleśnie ukazała Rumunom, że duża część ich planów wojennych może być trudna do zrealizowania, bowiem pierwotny plan wojny na dunajskim teatrze działań wojennych nie zakładał prowadzenia poważniejszych walk. Stąd też skierowane tam formalnie najsilniejsze liczebnie ugrupowanie, jakim była 3 Armia, składająca się jednak z dywizji najsłabiej wyposażonych, mających obsadzić bardzo rozległy obszar. Upadek Turtucai i następujące potem (wywierające zresztą jeszcze bardziej negatywne wrażenie) oddanie - właściwie bez walki - kolejnej twierdzy pozostającej pod rumuńską kontrolą od 1913 r., jaką była Sillistrii, spowodowało szybkie "przetasowania” w dowództwie rumuńskiej 3 Armii. Zdymisjonowany został jej dotychczasowy dowódca gen. dyw. Mihai Aslan, zaś jego miejsce zajął sam gen. A. Averescu. Dodatkowo, 3 Armia została podzielona na dwa ugrupowania: zgrupowanie strzegące brzegów Dunaju, które utrzymało nazwę 3 Armii, 
oraz Armię Dobrudży, z zadaniem obrony tego regionu (wspomaganej przez siły rosyjskie). Alexandru Averescu stanął więc na czele sił mających za zadanie powtórzenie manewru z 1913 r., tj. wykorzystania walk głównych sił bułgarskich na innym obszarze działań wojennych, przekroczenie Dunaju i marszu na Sofię, w celu wyłączenia Bułgarii z wojny, względnie przynajmniej zatrzymania ofensywy państw centralnych w Dobrudży. Decyzję o próbie przejścia do ofensywy na froncie południowym, słuszną - ale w zaistniałych warunkach spóźnioną i raczej już niewykonalną - podjęto pomimo przeciwnych opinii zgłaszanych np. przez gen. Constantina Prezana, który podtrzymywał zdanie o potrzebie kontynuacji działań na froncie północnym, skoro już zostały one i tak rozpoczęte. Była to kolejna cegiełka w sporze pomiędzy A. Averescu a C. Prezanem, który miał eksplodować w roku następnym przy okazji batalii na froncie mołdawskim.

Pierwotny plan proponowany przez A. Averescu zakładał jedynie pozorowanie przeprawy przez Dunaj (również miało to mieć miejsce w okolicach Flamânda). Rozpoczęto nawet przygotowania do takiego działania - budowę pozorowanych stanowisk artylerii, na których miały pojawić się drewniane repliki ciężkich dział rumuńskich, nakazano także gromadzenie materiału przeprawowego. W miarę możliwości plan działań zakładał także pojedyncze wypady na południowy brzeg Dunaju, niemniej jednak z tym zastrzeżeniem, by nie doprowadzić do większych strat wśród własnych żołnierzy. Generalnie, w pewnym sensie zakładano tu powtórkę działań z pierwszej połowy 1877 r., czyli sprzed oficjalnego wybuchu wojny rumuńsko-tureckiej ${ }^{19}$.

W celu ochrony przed możliwym działaniem austro-węgierskiej floty rzecznej, sprowadzono na miejsce także prawdziwą artylerię: 2 baterie dział $87 \mathrm{~mm}$, 2 baterie dział $105 \mathrm{~mm}$ i baterię haubic $150 \mathrm{~mm}$. Pojedyncze oddziały rumuńskie pojawiły się na bułgarskim brzegu Dunaju już 1/14 września 1916 r. Jednocześnie baterie umiejscowione $\mathrm{w}$ okolicy Flamândy i Turtucai rozpoczęły bombardowanie brzegu południowego, $\mathrm{z}$ zadaniem symulacji przygotowań do przeprawy rzeki przez wojska rumuńskie. Siły państw centralnych jednak nie dały się zwieść „rumuńskiej symulacji” i nadal prowadziły natarcie w Dobrudży. W tej sytuacji, gdy działania pozorowanie nie przyniosły rezultatu, należało je urealnić. Dnia 2/15 września miała miejsce narada wojenna w Periş, z udziałem króla, premiera Brătianu, szefa sztabu gen. Dumitru Iliescu i dowódców poszczególnych armii ${ }^{20}$. Dzień później (3/16 września) gen. A. Averescu przejął dowodzenie Grupą Armii „Południe”, w której skład weszły zarówno siły zgrupowane nad Dunajem, jak i w Dobrudży. Plan A. Averescu zakładał przejście Dunaju w strefie Giurgiu-Olteniţa. Bezpośrednie przygotowania do inwazji powierzono

19 A. Pogăciaș, Luptele de pe Dunăre și din Dobrogea în toamna anuluj 1916, „Tactica și strategia" 2018, nr 5, s. 28.

${ }^{20}$ P. OȚu, Mareșalul Constantin Prezan. Vocaţia datoriei, București 2008, s. 69. 
gen. Arthurovi Văitoianu, dowódcy 10 Dywizji Piechoty. Nie były one jednak prowadzone intencjonalnie z zachowaniem zasad tajności, gdyż najwyraźniej decydenci rumuńscy liczyli na to, iż pogłoski o możliwym desancie na tereny bułgarskie skłonią gen. Stefana Toszewa do spowolnienia tempa ataku w Dobrudży. Dowódca bułgarski najwidoczniej jednak nie uwierzył w pogłoski dochodzące z Bukaresztu i nadal kontynuował natarcie w kierunku północnym. Słusznie bowiem przewidywał, iż Rumuni nie mają dość sił do skutecznego działania na trzech kierunkach operacyjnych.

W międzyczasie, atak sił rumuńskich w Transylwanii napotkał na pierwsze przeszkody. Rumuni zostali pokonani pod Sibiu i odrzuceni do doliny Aluty, gdzie próbowali przejść do obrony. Wobec zmiany sytuacji na froncie północnym doszło do napięć pomiędzy generałami: A. Averescu i C. Prezanem. Ten drugi - jak już wspomniano - opowiadał się za wzmocnieniem oporu na froncie północnym ${ }^{21}$. Król Ferdynand 16/29 września 1916 r. zdecydował ostatecznie o rozpoczęciu ataku następnego dnia ${ }^{22}$. Przygotowań do niego nie udało się utrzymać w tajemnicy, bowiem 15/28 września ruchy wojsk rumuńskich zostały wyśledzone przez bułgarski samolot rozpoznawczy ${ }^{23}$.

Forsowanie Dunaju przebiegło sprawnie i nie napotkawszy oporu, Rumuni uchwycili 18 września/1 października 1916 r. przyczółek na bułgarskim brzegu. Wojska rumuńskie nie napotkały silniejszego oporu, walcząc początkowo właściwie jedynie z oddziałami bułgarskiej straży granicznej. Dowództwo bułgarskie zareagowało dość nerwowo na desant rumuński, natomiast feldmarszałek August von Mackensen podszedł do sprawy dość spokojnie, decydując się na podtrzymanie natarcia w Dobrudży i poprzestając na skierowaniu przeciw $\mathrm{Ru}$ munom jedynie części 217 Dywizji Piechoty, nadciągającej właśnie z południa. Niestety, Rumuni nie byli w stanie wykorzystać sukcesu, gdyż w tym samym czasie gen. Erich von Falkenhayn rozpoczął ofensywę państw centralnych w Siedmiogrodzie, co zmusiło Rumunów do zakończenia wszelkich działań ofensywnych i przejścia 3 października do defensywy. Dodatkowo most pontonowy był ciągle atakowany, zarówno przez austro-węgierską flotę rzeczną, jak i przez lotnictwo, co groziło jego zerwaniem i odcięciem jednostek, które już znalazły się na południowym brzegu. W związku z tym, były one ewakuowane $\mathrm{z}$ bułgarskiego brzegu od 20 września/3 października do 24 września/7 października i w ciągu kilku dni powróciły na północ ${ }^{24}$, by tam włączyć się do walk zmierzających do powstrzymania naporu wojsk państw centralnych, zresztą bezskutecznie.

\footnotetext{
${ }^{21}$ Ibidem, s. 73.

22 Idem, Mareșalul Alexandru Averescu. Militarul, omul politic, legenda, București 2005, s. 143.

${ }^{23}$ Ibidem, s. 30.

${ }^{24}$ A. PogĂCIAŞ, op. cit, s. 30.
} 
Przebieg trzech ukazanych kampanii wyraźnie pokazał, że choć Dunaj stanowił i stanowi do dnia dzisiejszego poważną przeszkodę wodną, to nie jest przeszkodą nie do przebycia. Jego długość i specyficzne warunki terenowe nie tworzą zeń skutecznej linii obronnej. Przy żadnej operacji desantowej siły czy to otomańskie, czy bułgarskie, nie stawiały oporu Rumunom przekraczającym Dunaj. Podobnie wyglądała sytuacja w nieopisanym tu przejściu wspomnianej rzeki przez wojska państw centralnych przez siły atakujące $\mathrm{z}$ południa $\mathrm{w}$ listopadzie 1916 r. pod dowództwem feldmarszałka A. von Mackensena, które zaskoczyło Rumunów i szybko doprowadziło do upadku Bukaresztu.

Andrzej Dubicki, Tadeusz Dubicki

\title{
THE DANUBE AS A NATURAL OBSTACLE IN ROMANIAN ARMY OPERATIONS
}

\begin{abstract}
Summary: The Danube is a significant natural obstacle. Since ancient times it has been used as a defense barrier, an important element of the defense system. Nevertheless, it often turned out that, despite its vastness, the great river was not a significant barrier to the opponent. Romanians have also benefited from this many times, shifting their troops to the southern shore in the wars of 1878, 1913 and 1916. In the article we present mainly the circumstances and course of crossing the Danube in these cases, together with an assessment of the crossing and its importance for the final conclusion of the campaign.
\end{abstract}

Keywords: Romania, Danube, War 1877-1879, Second Balkan War, First World War. 